\title{
Study of the incorporation of wood fiber to cassava, rice and potato biodegradable matrices.
}

\author{
${\text { Sandra } \text { Acosta }^{1 *} \text {, Paola Escalante }}^{1}$, María Villavicencio ${ }^{1}$, Cesar Moreira $^{1}$ \\ ESPOL Polytechnic University, Escuela Superior Politécnica del Litoral, Espol. Facultad de Ingenieria Mecánica y Ciencias de la \\ Producción. Campus Gustavo Galindo Km. 30.5 Vía Perimetral, P.O. Box 09-01-5863, Guayaquil, Ecuador. \\ cacosta@espol.edu.ec*, paofeesc@espol.edu.ec, mardvill@espol.edu.ec, , cemoreir@espol.edu.ec
}

\begin{abstract}
The present work is based in a study starting from the behavior and characterization of films made from a $2 \%$ total solids (TS) dispersion of easy accessibility raw materials such as, cassava starch $(Y)$, potato $(P)$ and rice $(A)$, combined with a protein i.e. gelatin (G) in a 50:50 ratio; adding guaiacum wood fiber of 75 and $150 \mu \mathrm{m}$ (Ff and Fg respectively) until 1\% (TS). Furthermore, glycerol was incorporated as plasticizer until $30 \%$ TS. The biodegradable films were elaborated by casting method. The films were characterized on the following parameters: thickness, water permeability and mechanical properties (Young modulus, tensile stress and elongation). It was found that the films made of AG-Ff and PG-Ff shown better barrier to the water vapor permeability with values of 2.5 and $2.4\left(\mathrm{~g} . \mathrm{mm} . \mathrm{KPa}^{-1} . \mathrm{h}^{-1} \cdot \mathrm{m}^{2}\right)$ respectively. The PG-Fffilm showed, also, better mechanical properties i.e. higher Force, Young modulus and tensile stress increasing with time, with the lower elasticity; the $\mathrm{YG}-\mathrm{Ff}$ and $\mathrm{YG}-\mathrm{Fg}$ films reported the higher elasticity, being this parameter of interest, we will continue with this formulae to other manufacturing processes.
\end{abstract}

Keywords-mechanical properties, water vapor permeability, casting, wood fiber.

\section{INTRODUCTION}

Plastics are widely used as packaging material and the common destiny of this material after usage is garbage bins for its disposal. Nevertheless, plastic waste is hard to degrade; situation that is aggravated due to a fast-growing world population. Indeed, it is expected an increment of about $37 \%$ of the solid waste generated worldwide by 2030. Latin America and Caribbean countries are not the exception, and nowadays about 370 thousand tons of waste is generated in their urban areas being 4\% plastics; which represents 16 million tons of plastic waste per year, its accumulation represents an environmental issue [1]. As a result, new technologies are being developed to reduce the environmental impact of packaging materials; these technologies include bio degradable polymers and biocomposites. Among the materials with high expectations to replace plastic, due to its availability, are the starches [2]. The matrices made from starches possess desirable properties such as flexibility, transparency and thermoplasticity [3]. Starches from different origins such as, cereal, legumes and tubers have been used as edible films for foodstuff, with the objective of extend their shelf life [4-8] Also, biodegradable materials have been studied and applied for vessel production using different manufacturing techniques. Lately, cassava starch alone or blended with other polymers has been subject of study, due to its physical properties, with the objective of improve or change its mechanical properties $[9,10]$.

Another starch of interest to produce films is the potato starch because its physicochemical properties changes depending of the variety and the location where it is cultivated [11-14], the potato starch matrices possess a low gelatinization temperature, low tendency to retro degradation and high resistance to enzymatic degradation [15].

Furthermore, the rice starch shown a high amylose content which results in higher gelatinization temperature, in addition, lower viscosity and retro degradation $[13,16]$, characteristics that results in films with low water vapor permeability and good mechanical properties.

Gelatin is widely used due to its films properties i.e. light protection and good oxygen barrier [17]. When films are made solely from gelatin, these shown good tensile stress resistance and mechanical properties but low elasticity, due to its internal configuration of hydrogen bonds, which is considered as a disadvantage when making films for vessels. Blending gelatin with other biopolymers have resulted in matrices with improved resistance to tensile stress and elongation due to collagen hydrolysis [18-21].

The addition of fibers, such as, bamboo, coconut, cotton husk, rice husk, graminid grasses, indeed bagasse, are used as a plastic reinforcement, being compression molding the more successful technology applied. Improved plastic matrices with better flexibility has been obtained when using polypropylene, polystyrene, epoxy, polyurethane, and phenolic resins with fibers such as linen, sisal, cotton, and a blend of linen/cotton [22]. Also, there are studies performed with incorporation of nano-particles aiming better mechanical properties of the film $[23,24]$, the results vary depending on the quality of the components and blends improving, as well, the water vapor permeation shield, oxygen barrier and optical properties $[25,26]$.

Also, it has been shown that adding foodstuff origin fiber to starch-glycerol matrices improve film characteristics, i.e. Young Modulus. Meanwhile, other fibers such as cassava bagasse or kraft paper added to matrices of biopolymers resulted in improved mechanical properties and its use as rigid containers for fresh foodstuff [23]. 
The advantage of natural fiber lies in the fact that are processed with ease, and are attractive for developing nations, where is easy to get these crops (hemp, white jute and linen) [27-31]. The aim of this work was to study the behavior and characterize biodegradable films, made of three different matrices i.e. a) cassava, b) potato and c) rice starches mixed with a protein (gelatin), with the addition of thin Guaiacum wood fiber ( 75 and $150 \mu \mathrm{m}$ particle size). It is awaited the added fiber would be compatible and improve the mechanical properties of the film, as a result, the formula can be used in the conformation of rigid containers by any method of common use in plastic manufacturing.

\section{MATERIALS AND METHODS}

\section{A. Raw material}

Potato starch (P) manufactured by Bob Red Mill - US (gelatinization at $67^{\circ} \mathrm{C}$ ), cassava starch (Y) manufactured by Goya - Brazil (gelatinization at $65^{\circ} \mathrm{C}$ ), rice starch (A) manufactured by Bob Red Mill - US (gelatinization at $78^{\circ} \mathrm{C}$ ), $240^{\circ}$ Bloom bovine Gelatin (G) manufactured by Merck (gelatinization $50^{\circ} \mathrm{C}$ ), Glycerol manufactured by Merck, two particle size $(75 \mu \mathrm{m}$ and $150 \mu \mathrm{m})$ guaiacum wood fiber, obtained from Atahualpa sawmill, Santa Elena - Ecuador, and hexahydrate magnesium nitrate saturated solution manufactured by Arcos Organic, US.

\section{B. Guiacum wood fiber particle size.}

The microsocope "Microscope Objective Stage Micrometer Calibration Slide" with a millimetric "Brand New" holder (0.01mm), with AmScope, Versión X64, 3.7.2671 (AmScope, Francés.) as interphase software was used. 12 repetitions of each assay were performed, selecting the more repeated size i.e. $75 \mu \mathrm{m}(\mathrm{Ff})$ y $150 \mu \mathrm{m}(\mathrm{Fg})$ (Fig. 1 and 2).

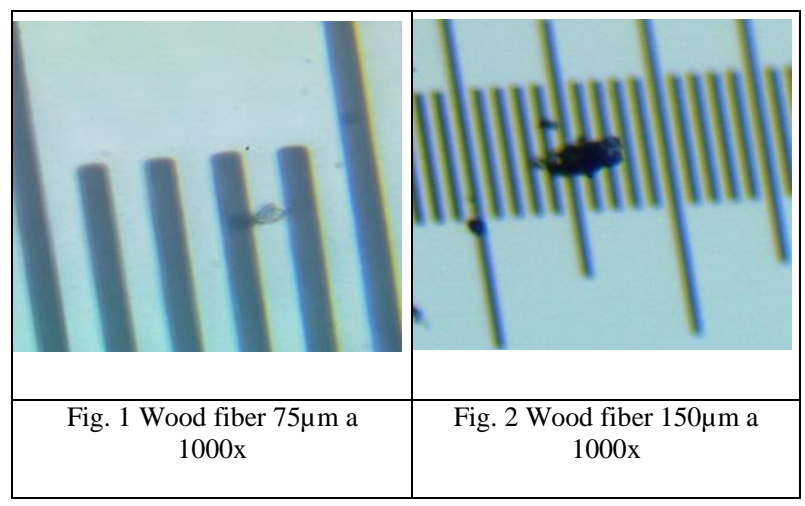

\section{Fiber Moisture}

It was measured by placing $1 \mathrm{~g}$ of sample inside of a Universal Memert (b200.0310 model SM-200) stove (Germany) until constant weight measured with an electronic Sartorious balance $(+0.0001 \mathrm{~g})$ made in Germany. The moisture percentage was calculated using equation (1). The measurement was performed by triplicate for the two most repeated fiber particle size.

$$
\% \mathrm{H}=\frac{\mathrm{P}_{1}-\mathrm{P}_{2}}{\mathrm{P}_{1}} \times 100
$$

Where:

$\% \mathrm{H}$ : Moisture percentage

$\mathrm{P}_{1}$ : Weight of the initial sample

$\mathrm{P}_{2}$ : Weight of the dried sample

\section{Film elaboration}

Films were made by mixing a $2 \%(w / w)$ TS dispersion of cassava, potato and rice starch with gelatin. The starches were dissolved using distilled water and gelatinized using a thermal bath (Thermo Scientific, $18902 \mathrm{~A}$, Germany.) at $100{ }^{\circ} \mathrm{C}$ by 30 minutes. Except, when using rice starch, where the temperature was reduced to $80^{\circ} \mathrm{C}$ and the time was increased by 15 minutes ( 45 minutes total). The gelatin was dissolved using distilled water, then the solution was placed over a heating plate for 30 minutes, keeping the temperature less than $80^{\circ} \mathrm{C}$. The cassava, potato and rice starch solution were mixed in 1:1 ratio with the gelatin solution ( $Y G, P G$ and $A G$ respectively). The fiber was incorporated to the polymer matrix until $1 \%(\mathrm{w} / \mathrm{w}) \mathrm{TS}$, then, the mix was left still by 20 minutes for fiber hydration; avoid in this way its agglomeration. After this, glycerol was added until reach $30 \%$ (w/w) TS. The dispersion without fiber was subjected to homogenization for 4 minutes at $12000 \mathrm{rpm}$, and 7 minutes for dispersion containing fiber; this variation of time allow fiber to break and blending with the rest of dispersion components, before placing it in the mold. When the dispersions reach 40 ${ }^{\circ} \mathrm{C}$ were placed in a Teflon mold for curing during 48 hours by natural convection; the films were stored for 7 days in a desiccator containing the saturated solution of hexahydrate magnesium nitrate for the initial time assay (Ti) and for 60 days for the final time assay (Tf). In Table 1 the prepared blends and used nomenclature for this assay is explained.

TABLE 1

Blends and film nomenclature

\begin{tabular}{|c|c|c|}
\hline $\begin{array}{c}\text { Starch + gelatin } \\
\text { (blanks) }\end{array}$ & $\begin{array}{c}\text { Starch + gelatin + } \\
\text { thin fiber }\end{array}$ & $\begin{array}{c}\text { Starch + gelatin + } \\
\text { thick fiber }\end{array}$ \\
\hline YG & YG-Ff & YG-Fg \\
\hline PG & PG-Ff & PG-Fg \\
\hline AG & AG-Ff & AG-Fg \\
\hline
\end{tabular}

\section{E. Film thickness}

The film thickness was measured in different locations with a total of 15 readings, an electronic digital micrometer (Millimar C1216 Mahr $\pm 0,001 \mathrm{~m}$ ) was used.

16 $^{\text {th }}$ LACCEI International Multi-Conference for Engineering, Education, and Technology: "Innovation in Education and Inclusion", 19-21 July 2018, Lima, Peru. 


\section{F. Water vapor permeability (PVA)}

The water vapor permeability was measured following a modification of the gravimetric method ASTM E96-95 [32]. For a $53-100 \%$ relative humidity $(\mathrm{RH})$ gradient and $25^{\circ} \mathrm{C}$, four repetitions were made. The samples were placed between the base and cap of a $4.9 \mathrm{~cm}$. diameter glass cup containing 15 $\mathrm{ml}$ of distilled water $(100 \% \mathrm{RH})$. Then, the cups were placed inside of a stabilized desiccator equipped with fans (CPU \& S.Tech $12 \mathrm{~V}$.) at the top, to keep a homogeneous atmosphere and assure a negligible resistance of the film surface. The desiccators were kept in a chamber with a controlled temperature of $25^{\circ} \mathrm{C}$ and $58-60 \% \mathrm{RH}$. The permeability study was performed by weighing each cup using a Mettler Toledo, XP2004S electronic scale $( \pm 0,0001 \mathrm{~g})$ at 1.5 hours interval for a period of 24 hours. The water vapor transmission was calculated using the slope obtained in the linear regression analysis after graphing the weight vs time and divided by the film area; it is expressed in g.mm. $\mathrm{kPa}^{-1} \cdot \mathrm{h}^{-1} \cdot \mathrm{m}^{-2}$.

\section{G. Mechanical properties}

The film mechanical properties were determined using a universal testing machine IDM S.L. (San Sebastian - Spain.) IDM test/MTC V1.301 with a "Registra 3 RG3" software version 2.79.7.281 ALDATEC Spain. For each formulation, 16 samples $(100 \times 15 \mathrm{~mm})$ were prepared. The maximum force used was $35 \mathrm{~N}$, with a maximum extension of $80 \mathrm{~mm}$ and the speed of elongation was $100 \mathrm{~mm} / \mathrm{min}$. The parameters evaluated were: Force (N), Young modulus (E), Tensile stress (TS) $(\mathrm{MPa})$, deformation until fracture $\mathrm{E}(\%)$.

\section{H. Scanning electron microscopy (SEM)}

A FEI ${ }^{\circledR}$ Inspect S50 (Netherlands) scanning microscope was used to study the morphology of the film with the more suitable mechanical properties. Rectangular films (6 x $1 \mathrm{~mm})$ were cut, and submerged in liquid nitrogen, then, immediately fractured to assure a clean cut. The samples were coated with gold to make them conductors (about 1.5 minutes), using an EMITECH SC760 mini sputter coater, and examined using an accelerating voltage of $10 \mathrm{KV}$. Images were taken by triplicate.

\section{Statistics}

Data was subjected to analysis of variance (ANOVA) using Statgraphic Plus 5.1 software (Manugistics Corp, Rockville - MD).

The method of least significant difference was applied with a $95 \%$ of confidence interval, where the different superscript $\mathrm{a}, \mathrm{b}$ and $\mathrm{c}$ inside a column indicate significative differences among different formulations for a single storage time; on the other hand, the $\mathrm{x}$ superscript inside the same formulation indicates significative differences among the different times of storage for a single formulation.

\section{RESULTS AND DISCUSSION}

\section{A. Fiber moisture}

The fiber moisture was determined in the two-different particle size ( 75 and $150 \mu \mathrm{m})$, as it can be seen in Table 2, Ff is the film showing less moisture (7\%).

TABLE 2.

Moisture \% of the thin (Ff) and thick (Fg) fiber.

\begin{tabular}{|c|c|}
\hline \multicolumn{2}{|c|}{ Moisture $(\%)$} \\
\hline Fiber Size $(\mu \mathrm{m})$ & Average \\
\hline$(\mathrm{Ff}) 75$ & $7,0(0,9)$ \\
\hline$(\mathrm{Fg}) 150$ & $9,4(0,6)$ \\
\hline
\end{tabular}

This is related with the results obtained when determining Water Vapor Permeability (WVP), where the Ff samples shown lower values, being better barrier to the water vapor. These results of moisture are similar to the findings of [33], who worked with guaiacum wood dried using natural convection with a $12 \%$ moisture.

\section{B.Film thickness}

Film thickness results for different formulation are shown in Table 3. It can be seen that blanks (YG, PG, and AG) reported the lowest values for $\mathrm{Ti}$ and $\mathrm{Tf}$, meanwhile $\mathrm{YG}$ and AG blanks are the only ones without significative differences, being the more stables. Films shown significant difference, among them and along the time, when fiber was added to the films. Also, it was observed that Ff and Fg films incremented their thickness along time, being the matrix made of potato starch the ones with higher increment.

TABLE 3

Thickness of the films with and without fiber at 2 storage periods ( 7 and 60 days)

\begin{tabular}{|c|c|c|}
\hline \multicolumn{3}{|c|}{ Thickness $\mu \mathrm{m}^{\mid}$} \\
\hline Films & $\begin{array}{c}\text { T. Initial } \\
(7 \text { days })\end{array}$ & $\begin{array}{c}\text { T. Final } \\
(60 \text { days })\end{array}$ \\
\hline YG & $66,78(3,42)^{(\mathrm{a})(\mathrm{x})}$ & $68,77(2,34)^{(\mathrm{a})(\mathrm{x})}$ \\
YG-Ff & $82,26(5,19)^{(\mathrm{b})(\mathrm{x})}$ & $86,50(4,44)^{(\mathrm{b})(\mathrm{y})}$ \\
YG-Fg & $87,86(4,61)^{(\mathrm{c})(\mathrm{x})}$ & $92,23(5,25)^{(\mathrm{c})(\mathrm{y})}$ \\
\hline PG & $56,88(3,48)^{(\mathrm{a})(\mathrm{x})}$ & $83,22(4,17)^{(\mathrm{a})(\mathrm{y})}$ \\
PG-Ff & $77,10(8,90)^{(\mathrm{b})(\mathrm{x})}$ & $103,75(1,86)^{(\mathrm{b})(\mathrm{y})}$ \\
PG-Fg & $87,07(8,29)^{(\mathrm{c})(\mathrm{x})}$ & $108,18(2,96)^{(\mathrm{b})(\mathrm{y})}$ \\
\hline AG & $66,08(3,75)^{(\mathrm{a})(\mathrm{x})}$ & $67,98(1,72)^{(\mathrm{a})(\mathrm{x})}$ \\
AG-Ff & $76,14(5,00)^{(\mathrm{b})(\mathrm{x})}$ & $82,13(2,56)^{(\mathrm{b})(\mathrm{y})}$ \\
AG-Fg & $75,22(5,47)^{(\mathrm{b})(\mathrm{x})}$ & $87,93(4,95)^{(\mathrm{c})(\mathrm{y})}$ \\
\hline
\end{tabular}

These results can be related to the hydrophilic nature of the biodegradable films, and the correlation of positive slope with

$1^{\text {th }}$ LACCEI International Multi-Conference for Engineering, Education, and Technology: "Innovation in Education and Inclusion”, 19-21 July 2018, Lima, Peru. 
water vapor permeability and thickness [32,33,34,35] observed with the potato starch matrix with the two sizes of fiber particles. It is considered that when the film thickness increase, the resistance to mass transfer through it increases as well; resulting in an increased equilibrium water vapor partial pressure at the interior surface of the film. Also, the thickness increment may be related to changes in the film structure due to the water swollen in the polymer $[36,7]$. When fibers are added to a biodegradable film, the final thickness of the film increases, because it exists a moisture absorption provoked by the fibers and its particle size; being directly proportional with the moisture, verifying the obtained results.

\section{Water vapor permeability (WVP)}

It was observed that the blanks YG, PG and AG possess the lowest values of WVP at either Ti or Tf, reason why it can be considered as a good barrier. The film Ag-Ff showed a lower value of WVP at Tf, this result suggests that it is a good barrier. When fiber is added to the films, the films shown a similar behavior among them. The statistical analysis suggests that there are not significant differences among them and times when the films contains fiber (Table 4).

The WVP of all films increase with time, but the AG-Ff which decreases. This result suggest that the structure and bonds turn stronger with time, making this film a good barrier. Comparing all the films containing Ff with those containing $\mathrm{Fg}$, the best WVP are the films containing Ff.

TABLE 4.

Water vapor permeability (WPV) of the films with and without fiber at 2 storage periods ( 7 and 60 days).

\begin{tabular}{|c|c|c|}
\hline \multicolumn{3}{|c|}{ WPV $\left(\mathrm{g} \cdot \mathrm{mm} \cdot \mathrm{Kpa}^{-1} \cdot \mathrm{h}^{-1} \cdot \mathrm{m}^{-2}\right)$} \\
\hline Films & Ti $(7$ days $)$ & Tf $(60$ days $)$ \\
\hline YG & $1,32(0,35)^{(\mathrm{a})(\mathrm{x})}$ & $2,07(0,76)^{(\mathrm{a})(\mathrm{x})}$ \\
YG-Ff & $2,45(0,40)^{(\mathrm{b})(\mathrm{x})}$ & $2,55(1,25)^{(\mathrm{a})(\mathrm{x})}$ \\
YG-Fg & $1,98(0,60)^{(\mathrm{b})(\mathrm{x})}$ & $2,80(0,00)^{(\mathrm{a})(\mathrm{x})}$ \\
\hline PG & $0,92(0,19)^{(\mathrm{a})(\mathrm{x})}$ & $2,74(0,14)^{(\mathrm{a})(\mathrm{y})}$ \\
PG-Ff & $2,21(0,37)^{(\mathrm{b})(\mathrm{x})}$ & $2,54(1,42)^{(\mathrm{a})(\mathrm{x})}$ \\
PG-Fg & $1,78(0,36)^{(\mathrm{b})(\mathrm{x})}$ & $3,72(1,08)^{(\mathrm{a})(\mathrm{y})}$ \\
\hline AG & $1,11(0,19)^{(\mathrm{a})(\mathrm{x})}$ & $2,14(0,48)^{(\mathrm{a})(\mathrm{y})}$ \\
AG-Ff & $2,79(0,63)^{(\mathrm{a})(\mathrm{x})}$ & $2,43(0,29)^{(\mathrm{a})(\mathrm{x})}$ \\
AG-Fg & $2,19(0,62)^{(\mathrm{b})(\mathrm{x})}$ & $2,67(0,38)^{(\mathrm{a})(\mathrm{x})}$ \\
\hline
\end{tabular}

These results are similar to the finds reported by $[37,38]$ when studying the addition of nanoparticles to starch, particularly the reduction of moisture transference, which results in a low water permeability. Reference [39] results, when working with corn starch films and $15 \%$ of Taro nano particle, suggest the formation of aggregates that ended diminishing the WVP, which is related with the indirect relation between longest diffusion pathway and lower WVP [40 - 42].

\section{Mechanical Properties}

The measured mechanical properties i.e. Force (F), Young modulus (E), tensile stress (TS) and deformation (D) determine the inter and intra molecular characteristics of the biodegradable films. The addition of fiber should result in an increment of the values for F, E and TS; however, an excess of fiber would make the films brittle $[7,43]$. The $F$ of the formulated films at $\mathrm{Ti}$ and $\mathrm{Tf}$ have similar behavior to the values found in the parameter TS (Table 5). On the other hand, in the films without fiber the force decreases with the time, contrary to when fiber is added to the formula. The film PG-Ff shown a value of $20 \mathrm{~N}$, therefore, is more rigid than the other films. These results are in agreement with the values reported by [44] in wheat starch when using different glycerol $\%$ and $\mathrm{RH}$, their results are comparable to our results only when working with $20 \%$ of glycerol and $11 \%$ RH. Table 5 also shown TS of the formulated films at Ti and Tf. The film with higher value of TS is the PG-Ff at Tf, comparing this value with the ones obtained at $\mathrm{Ti}$, we can suggest that TS increase along the storage time.

Reference $[1,40]$, found that the effect of fiber particles in films improve its mechanical properties with the time. For rice starch films with $5 \%$ of nanoparticles reference [1], reported a TS value of $10 \mathrm{MPa}$, these are in well agreement with the value of $8-14 \mathrm{MPa}$ found in this study when using $1 \%$ of fiber for the $\mathrm{Ff}$ and $\mathrm{Fg}$ films between the 2 assay times.

Reference [45], shown that TS increases in the 3\% cassava starch film when cellulose fiber was added, this result suggests that the films became more rigid, similar to the results reported by [46], when working with wheat starch films with added cellulose fiber. The results on the parameter D are higher for the YG films, either for $\mathrm{Ff}$ and $\mathrm{Fg}$. It was observed that the YG film increased at Tf with the time, these results are opposed to the reported by [47], who work with pea starch and rice fiber, where the values decreased at Tf. This tendency is similar to the results obtained in the films containing starch (PG and AG) at Tf, same behavior reported by [45,46], where the elongation decreases in the films with added fiber.

The Young modulus (E) is an indicator of the film rigidness, as a result, the higher the value of $\mathrm{E}$ the more rigid the material [44]. Result suggests that the more rigid film is the PG-Ff in agreement with the higher values obtained for $\mathrm{F}$ $y$ TS. Overall the value of $E$ decrease with the time in the films that contain cassava starch and fiber, contrary to the films made from potato and rice starch with added fiber. Opposite to the results reported by [48] where the rice starch with added cotton fiber and $2 \%$ of stearic acid reported an increment of $\mathrm{E}$ when the \% of fiber increased until $10 \%$, higher concentrations resulted in lower values of E. Similar results were reported by [49], when working with cassava starch and coconut fiber he reported higher values of $E$ when increasing the content of fiber.

16 $^{\text {th }}$ LACCEI International Multi-Conference for Engineering, Education, and Technology: "Innovation in Education and Inclusion", 19-21 July 2018, Lima, Peru. 
TABLE 5.

Mechanical properties Force (F), Young Modulus (E), Tensile stress (TS), Deformation (D) of film made from cassava starch, potato and rice with gelatin with and without fiber (Ff-Fg) and two storage time (7 and 60 days ).

\begin{tabular}{|c|c|c|c|c|c|c|c|c|}
\hline \multirow[b]{2}{*}{ Films } & \multicolumn{2}{|c|}{ FORCE "F" (N) } & \multicolumn{2}{|c|}{ YOUNG MODULUS “E” (Mpa) } & \multicolumn{2}{|c|}{ TENSILE STRESS “TS” (Mpa) } & \multicolumn{2}{|c|}{ DEFORMATIÓN “D” (\%) } \\
\hline & Ti (7 days) & $\operatorname{Tf}(60$ days $)$ & Ti (7 days) & $\operatorname{Tf}(60$ days $)$ & Ti (7 days) & $\operatorname{Tf}(60$ days $)$ & Ti (7 days) & $\operatorname{Tf}(60$ days $)$ \\
\hline YG & $16,64(2,09)^{(\mathrm{a})(\mathrm{x})}$ & $12,81(1,85)^{(\mathrm{a})(\mathrm{y})}$ & $871,37(54,83)^{(\mathrm{a})(\mathrm{x})}$ & $687,45(99,39)^{(\mathrm{a})(\mathrm{y})}$ & $16,61(2,09)^{(\mathrm{a})(\mathrm{x})}$ & $12,56(1,82)^{(\mathrm{a})(\mathrm{y})}$ & $18,72(4,85)^{(\mathrm{a})(\mathrm{x})}$ & $23,26(5,92)^{(\mathrm{a})(\mathrm{x})}$ \\
\hline YG-Ff & $11,67(2,78)^{(b)(x)}$ & $12,35(1,46)^{(\mathrm{a})(\mathrm{x})}$ & $670,39(88,12)^{(\mathrm{b})(\mathrm{x})}$ & $216,90(54,11)^{(\mathrm{b})(\mathrm{y})}$ & $9,46(2,26)^{(b)(x)}$ & $9,15(1,08)^{(\mathrm{b})(\mathrm{y})}$ & $20,40(3,31)^{(\mathrm{a})(\mathrm{x})}$ & $57,91(14,66)^{(b)(y)}$ \\
\hline YG-Fg & $17,46(4,04)^{(\mathrm{a})(\mathrm{x})}$ & $14,76(2,42)^{(b)(x)}$ & $923,85(93,12)^{(\mathrm{a})(\mathrm{x})}$ & $412,61(43,15)^{(\mathrm{c})(\mathrm{y})}$ & $13,50(3,40)^{(\mathrm{c})(\mathrm{x})}$ & $10,67(1,75)^{(\mathrm{b})(\mathrm{y})}$ & $12,91(2,84)^{(\mathrm{b})(\mathrm{x})}$ & $25,87(11,75)^{(a)(y)}$ \\
\hline PG & $15,85(3,77)^{(\mathrm{a})(\mathrm{x})}$ & $14,24(2,34)^{(\mathrm{a})(\mathrm{x})}$ & $\underset{(\mathrm{a})(\mathrm{x})}{1233,69(65,57)}$ & $\underset{\text { (a)(y) }}{1011,56(258,79)}$ & $19,30(4,01)^{(\mathrm{a})(\mathrm{x})}$ & $11,91(1,96)^{(\mathrm{ab})(\mathrm{y})}$ & $17,42(3,43)^{(a)(x)}$ & $10,21(5,30)^{(a)(y)}$ \\
\hline PG-Ff & $10,92(2,14)^{(b)(x)}$ & $20,12(5,20)^{(b)(y)}$ & $539,78(77,91)^{(\mathrm{b})(\mathrm{x})}$ & $1727,86(70,45)^{(\mathrm{b})(\mathrm{y})}$ & $8,86(1,85)^{(\mathrm{b})(\mathrm{x})}$ & $14,44(3,73)^{(\mathrm{a})(\mathrm{y})}$ & $18,82(4,75)^{(\mathrm{a})(\mathrm{x})}$ & $7,55(5,25)^{(\mathrm{a})(\mathrm{y})}$ \\
\hline PG-Fg & $11,13(2,51)^{(b)(x)}$ & $14,45(3,43)^{(\mathrm{a})(\mathrm{y})}$ & $438,08(93,36)^{(\mathrm{c})(\mathrm{x})}$ & $844,52(92,48)^{(\mathrm{c})(\mathrm{y})}$ & $8,79(1,53)^{(\mathrm{b})(\mathrm{x})}$ & $11,35(3,52)^{(b)(y)}$ & $23,99(3,31)^{(b)(x)}$ & $6,54(5,04)^{(\mathrm{a})(\mathrm{y})}$ \\
\hline AG & $15,58(4,13)^{(\mathrm{a})(\mathrm{x})}$ & $10,46(4,41)^{(b)(y)}$ & $\underset{\text { (a)(x) }}{1054,63(57,73)}$ & $787,66(33,09)^{(\mathrm{a})(\mathrm{y})}$ & $15,71(4,16)^{(\mathrm{a})(\mathrm{x})}$ & $10,23(4,04)^{(\mathrm{a})(\mathrm{y})}$ & $12,77(5,41)^{(\mathrm{a})(\mathrm{x})}$ & $10,33(6,40)^{(\mathrm{a})(\mathrm{x})}$ \\
\hline AG-Ff & $10,63(1,20)^{(b)(x)}$ & $15,25(3,43)^{(b)(y)}$ & $407,24(57,38)^{(b)(x)}$ & $624,56(94,40)^{(\mathrm{b})(\mathrm{y})}$ & $10,72(1,20)^{(b)(x)}$ & $12,1(2,72)^{(\mathrm{a})(\mathrm{x})}$ & $29,72(4,81)^{(\mathrm{b})(\mathrm{x})}$ & $19,10(9,11)^{(b)(y)}$ \\
\hline AG-Fg & $8,08(1,49)^{(\mathrm{b})(\mathrm{x})}$ & $13,78(3,30)^{(b)(y)}$ & $618,05(13,69)^{(\mathrm{c})(\mathrm{x})}$ & $636,13(61,46)^{(b)(x)}$ & $8,14(1,50)^{(\mathrm{b})(\mathrm{x})}$ & $10,45(2,51)^{(\mathrm{a})(\mathrm{x})}$ & $16,81(4,92)^{(\mathrm{a})(\mathrm{x})}$ & $19,78(6,28)^{(\mathrm{b})(\mathrm{x})}$ \\
\hline
\end{tabular}

\section{E. Scanning electron microscopy (SEM)}

Figures 3 and 4 shown micrographs of the matrix PG with added fine and thick fiber ( $\mathrm{Ff}$ and $\mathrm{Fg}$, respectively) using $1500 \mathrm{x}$ magnification. It can be seen that matrices without added fiber (starch and gelatin only) are rippled, similar to the findings of [19]. The films with added fiber shown a good incorporation of the fiber to the matrix, this finding is in agreement to [45] observations, who reported a homogeneous distribution of fibers without crack or pores when added different concentrations of soft wood fiber to a starch matrix; contributing to better mechanical properties. Nonetheless, concentrations of fiber $1 \%$ or higher, shown a poor interface adhesion due to the appearance of agglomerates [2]. Importantly, the distribution of the fiber along of the matrix varies depending the type of fiber used ( $\mathrm{Ff}$ or $\mathrm{Fg}$ ).

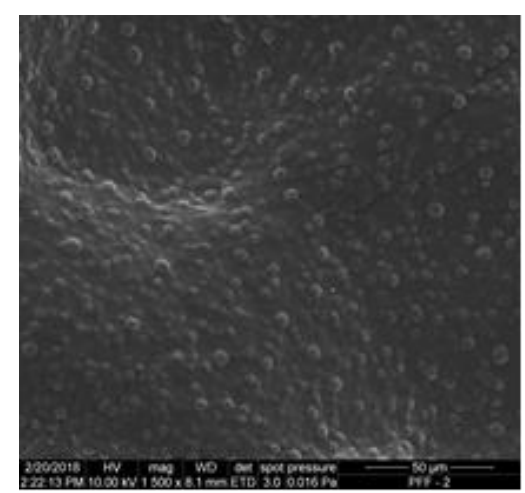

Fig. 3 SEM of PG-Ff film using 1500x augmentation

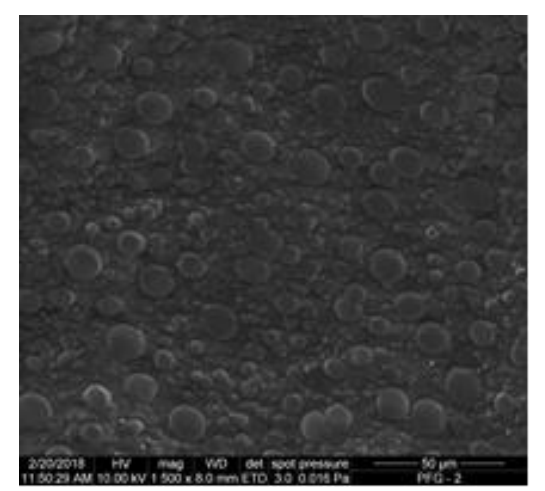

Fig. 4 SEM of PG-Fg using 1500x de augmentation

\section{CONCLUSIONS}

The results shown that the addition of wood fiber (Guaiacum) to the films made from blending cassava, potato and rice starch, with gelatin in a 50:50 ratio, affected the thickness and water vapor permeability of the film, due to when fiber was added to the matrix, the thickness increased along the observation time (7 to 60 days). As a result, the resistance of the film to mass transfer increases, improving the barrier properties; being the film made from potato starch and gelatin "PG" with both fiber particle size the ones showing higher values in the measured parameters. Being the film with thin fiber " $F f$ ", the one who shown better barrier, with better net compaction, followed by films made from cassava and gelatin (YG). The characterization for mechanical properties shown that the film PG-Ff had higher rigidity, therefore, it

$\mathbf{1 6}^{\text {th }}$ LACCEI International Multi-Conference for Engineering, Education, and Technology: "Innovation in Education and Inclusion", 19-21 July 2018, Lima, Peru. 
reported higher values of force, tensile stress and Young modulus with a lower elongation compared to the other film formulas. The films made from cassava and gelatin "YG" regardless of the fiber shown better elasticity. Therefore, the results suggest that the potato starch, gelatin and thin fiber (PG with Ff) matrix shown the best force characteristics, on the other hand, the cassava starch, gelatin and thin fiber (YG with Ff) matrix shown the best elongation, resulting in candidates for thermoforming in similar conditions to the plastics. The morphological study using SEM shown a good incorporation of the fiber to the PG matrix without cracks or pull outs, for both used fibers. Therefore, future work aims to apply thermoforming to the, developed, potato and cassava matrices with added fine fiber to obtain a biodegradable compostable container able to protect products sensible to transportation, similar to the plastic protection used in foodstuff export.

\section{REFERENCES}

[1] K. Piyada, S. Waranyou and W. Thawien, '"Mechanical, thermal and structural properties of rice starch films reinforced with rice starch nanocrystals." International Food Research Journal, 2013 vol. 20, no. 1 .

[2] N. Savadekar and S. Mhaske, '"Synthesis of nano cellulose fibers and effect on thermoplastics starch based films," Carbohydr.Polym., 2012 vol. 89 , no. 1, pp. 146-151.

[3] J. Bonilla, L. Atarés, M. Vargas and A. Chiralt, '"Properties of wheat starch film-forming dispersions and films as affected by chitosan addition," J.Food Eng., 2013 vol. 114, no. 3, pp. 303-312.

[4] M. Stading, Å. Rindlav-Westling and P. Gatenholm, '"Humidityinduced structural transitions in amylose and amylopectin films," Carbohydr.Polym., 2001 vol. 45, no. 3, pp. 209-217.

[5] D. Renard, G. Della Valle and Y. Popineau, "'Plant biopolymer science: food and non-food applications,", vol. 276, 2002.

[6] S. Mali, L.B. Karam, L.P. Ramos and M.V.E. Grossmann, '"Relationships among the composition and physicochemical properties of starches with the characteristics of their films," J.Agric.Food Chem., 2004 vol. 52, no. 25, pp. 7720-7725.

[7] A. Jiménez, M.J. Fabra, P. Talens and A. Chiralt, '"Edible and biodegradable starch films: a review," Food and Bioprocess Technology, 2012 vol. 5, no. 6, pp. 2058-2076.

[8] A.K. Asghari, I. Norton, T. Mills, P. Sadd and F. Spyropoulos, '"Interfacial and foaming characterisation of mixed protein-starch particle systems for food-foam applications," Food Hydrocoll., 2016 vol. 53, pp. 311-319.

[9] K. Kaewtatip and V. Tanrattanakul, "'Preparation of cassava starch grafted with polystyrene by suspension polymerization," Carbohydr.Polym., 2008 vol. 73, no. 4, pp. 647-655.

[10] P.R. Salgado, V.C. Schmidt, S.E.M. Ortiz, A.N. Mauri and J.B. Laurindo, '"Biodegradable foams based on cassava starch, sunflower proteins and cellulose fibers obtained by a baking process," J.Food Eng., 2008 vol. 85, no. 3, pp. 435-443.

[11] B.K. Patel and K. Seetharaman, '"Effect of heating rate on starch granule morphology and size," Carbohydr.Polym., 2006 vol. 65, no. 3, pp. 381-385.

[12] A. Kaur, N. Singh, R. Ezekiel and H.S. Guraya, '"Physicochemical, thermal and pasting properties of starches separated from different potato cultivars grown at different locations," Food Chem., 2007 vol. 101, no. 2, pp. 643-651.

[13] S. Kaur, P.S. Panesar, M.B. Bera and S. Kumari, '"Physicochemical, textural, pasting, and in vitro digestion properties of some basmati and

\section{ACKNOWLEDGMENT}

We would like to thank the laboratory of metrological assays and materials (LEMAT - Guayaquil, Ecuador) and to Sigmaplast S.A. (Quito, Pifo - Ecuador) for their access to required equipment, help with laboratory analysis and the assistance given by specialized technical personnel.

non-basmati rice cultivars," Int.J.Food Prop., 2013 vol. 17, no. 5, pp. 1055-1066.

[14] Q. Liu, R. Tarn, D. Lynch and N.M. Skjodt, "'Physicochemical properties of dry matter and starch from potatoes grown in Canada," Food Chem., 2007 vol. 105, no. 3, pp. 897-907.

[15] T. Sun, H.N. Lærke, H. Jørgensen and K.E.B. Knudsen, '"The effect of extrusion cooking of different starch sources on the in vitro and in vivo digestibility in growing pigs," Anim.Feed Sci.Technol., 2006 vol. 131 , no. 1, pp. 67-86.

[16] L. Wang, B. Xie, J. Shi, S. Xue, Q. Deng, Y. Wei and B. Tian, "'Physicochemical properties and structure of starches from Chinese rice cultivars," Food Hydrocoll., 2010 vol. 24, no. 2, pp. 208-216.

[17] B. Cuq, N. Gontard and S. Guilbert, '"Proteins as agricultural polymers for packaging production," Cereal Chem., 1998 vol. 75, no. 1, pp. 1-9.

[18] E. Amici, A. Clark, V. Normand and N. Johnson, "'Interpenetrating network formation in agarose-sodium gellan gel composites," Carbohydr.Polym., 2001 vol. 46, no. 4, pp. 383-391.

[19] A. Al-Hassan and M. Norziah, '"Starch-gelatin edible films: Water vapor permeability and mechanical properties as affected by plasticizers," Food Hydrocoll., 2012 vol. 26, no. 1, pp. 108-117.

[20] F.M. Fakhouri, D. Costa, F. Yamashita, S.M. Martelli, R.C. Jesus, K. Alganer, F.P. Collares-Queiroz and L.H. Innocentini-Mei, "'Comparative study of processing methods for starch/gelatin films," Carbohydr.Polym., 2013 vol. 95, no. 2, pp. 681-689.

[21] S. Acosta, A. Jiménez, M. Cháfer, C. González-Martínez and A. Chiralt, '"Physical properties and stability of starch-gelatin based films as affected by the addition of esters of fatty acids," Food Hydrocoll., 2015 vol. 49, pp. 135-143.

[22] P.F. Sommerhuber, T. Wang and A. Krause, '"Wood-plastic composites as potential applications of recycled plastics of electronic waste and recycled particleboard," J.Clean.Prod., 2016 vol. 121, pp. 176-185.

[23] K.N. Matsui, F.D.S. Larotonda, S.S. Paes, D.d.B. Luiz, A.T.N. Pires and J. Laurindo, '"Cassava bagasse-Kraft paper composites: analysis of influence of impregnation with starch acetate on tensile strength and water absorption properties," Carbohydr.Polym., 2004 vol. 55, no. 3, pp. 237-243.

[24] A. C. Souza, Benze, R., Ferrao, E.S., Ditchfield, C., Coelho, A., \& Tadini, C.C. (2012). Cassava starch biodegradable films: Influence of glycerol and clay nanoparticles content on tensile and barrier properties and glass transition temperature. LWT-Food Science and Technology, 46 (1), pp. 110-117.

[25] Villada, H. S, Acosta, H.A., \& Velasco, R.J. (2007). Biopolymers Naturals used in biodegradable packaging. Temas Agrarios, 12(2), pp. 5-13.

Sitio

web:

$16^{\text {th }}$ LACCEI International Multi-Conference for Engineering, Education, and Technology: "Innovation in Education and Inclusion", 19-21 July 2018, Lima, Peru. 
[26] http://docplayer.es/18462055-Biopolimeros-naturales-usados-enempaques-biodegradables-biopolymers-naturals-used-inbiodegradable-packaging.html

[27] A. Shi, L. Wang, D. Li and B. Adhikari, "'Characterization of starch films containing starch nanoparticles: Part 1: Physical and mechanical properties," Carbohydr.Polym., 2013 vol. 96, no. 2, pp. 593-601.

[28] J. Gassan, A. Chate and A.K. Bledzki, '"Calculation of elastic properties of natural fibers," J.Mater.Sci., 2001 vol. 36, no. 15, pp. 3715-3720.

[29] A.K. Mohanty, M. Misra and L.T. Drzal, '"Natural fibers, biopolymers, and biocomposites,", 2005.

[30] T. Majewski, A. Bledzki, M. Murr, D. Szwedowicz and K. Sudhakar, "'Quality of measurement methods for mechanical testing of PPbiocomposites," Polym.Plast.Technol.Eng., 2011 vol. 50, no. 3, pp. 239-244.

[31] A. Bledzki, O. Faruk and A. Mamun, '"Abaca fibre reinforced PP composites: influence of fibre length and compounding processes on the mechanical properties," J Polimery, 2007 vol. 53, no. 2, pp. 42-53.

[32] A. Bledzki, A. Mamun and O. Faruk, "'Abaca fibre reinforced PP composites and comparison with jute and flax fibre PP composites," eXPRESS polymer letters, 2008 vol. 1, no. 11, pp. 755-762.

[33] T.H. McHugh, R. Avena - Bustillos and J. Krochta, '"Hydrophilic edible films: modified procedure for water vapor permeability and explanation of thickness effects," J.Food Sci., 1993 vol. 58, no. 4, pp. 899-903.

[34] Ibáñez, A., Henry, P., \& García, M. (2007). Estudio de las Propiedades Físico-Mecánicas De Cinco Especies Maderables del Macizo Montañoso Sagua-Nipe-Baracoa. Revista Forestal Baracoa, 26(1).

[35] Gennadios, A.H. Brandenburg, J.W. Park, C.L. Weller and R.F. Testin, "'Water vapor permeability of wheat gluten and soy protein isolate films," Industrial Crops and Products, 1994 vol. 2, no. 3, pp. 189-195.

[36] H.J. Park and M.S. Chinnan, "'Gas and water vapor barrier properties of edible films from protein and cellulosic materials," J.Food Eng., 1995 vol. 25, no. 4, pp. 497-507.

[37] H. Park, C. Weller, P. Vergano and R. Testin, '"Permeability and mechanical properties of cellulose - based edible films," J.Food Sci., 1993 vol. 58, no. 6, pp. 1361-1364.

[38] H. Pan, D. Xu, Q. Liu, H.Q. Ren and M. Zhou, '"Preparation and Characterization of Corn Starch-Nanodiamond Composite Films,", 2005 vol. 469, pp. 156-161.
[39] H. Wu, C. Liu, J. Chen, P.R. Chang, Y. Chen and D.P. Anderson, '"Structure and properties of starch/ $\alpha$-zirconium phosphate nanocomposite films," Carbohydr.Polym., 2009 vol. 77, no. 2, pp. 358-364.

[40] L. Dai, C. Qiu, L. Xiong and Q. Sun, "'Characterisation of corn starchbased films reinforced with taro starch nanoparticles," Food Chem., 2015 vol. 174 , pp. 82-88.

[41] E. Kristo and C.G. Biliaderis, "'Physical properties of starch nanocrystal-reinforced pullulan films," Carbohydr.Polym., 2007 vol. 68 , no. 1 , pp. $146-158$

[42] B. Duan, P. Sun, X. Wang and C. Yang, '"Preparation and properties of starch nanocrystals/carboxymethyl chitosan nanocomposite films," Starch - Stärke, 2011 vol. 63, no. 9, pp. 528-535.

[43] A. Shi, L. Wang, D. Li and B. Adhikari, '"Characterization of starch films containing starch nanoparticles: Part 1: Physical and mechanical properties," Carbohydr.Polym., 2013 vol. 96, no. 2, pp. 593-601.

[44] T.J. Gutiérrez, M.S. Tapia, E. Pérez and L. Famá, '"Structural and mechanical properties of edible films made from native and modified cush-cush yam and cassava starch," Food Hydrocoll., 2015 vol. 45, pp. 211-217.

[45] A. Farahnaky, B. Saberi and M. Majzoobi, "'Effect of glycerol on physical and mechanical properties of wheat starch edible films," J.Texture Stud., 2013 vol. 44, no. 3, pp. 176-186

[46] C.M. Müller, J.B. Laurindo and F. Yamashita, '"Effect of cellulose fibers addition on the mechanical properties and water vapor barrier of starch-based films," Food Hydrocoll., 2009 vol. 23, no. 5, pp. 13281333.

[47] D. Lu, C. Xiao and S. Xu, "Starch-based completely biodegradable polymer materials," Express polymer letters, 2009 vol. 3, no. 6, pp. 366-375

[48] A. Cano, A. Jiménez, M. Cháfer, C. Gónzalez and A. Chiralt, "'Effect of amylose: amylopectin ratio and rice bran addition on starch films properties," Carbohydr.Polym., 2014 vol. 111, pp. 543-555.

[49] J. Prachayawarakorn, P. Sangnitidej and P. Boonpasith, '"Properties of thermoplastic rice starch composites reinforced by cotton fiber or lowdensity polyethylene," Carbohydr.Polym., 2010 vol. 81, no. 2, pp. 425-433.

[50] Lomeli, M.,Satyanarayana, K., Iwakiri, S., Bolzom, G., Tanobe, V., \& Flores-Sahagun, T. (2011). Study of the properties of biocomposites. Part I. Cassava starch-green coir fibers from Brazil. Carbohydrate Polymers, 2011 vol 86, pp. 1712-1722. 